\title{
THE POSSIBILITY OF TEACHING OPERATIONAL RESEARCH IN THE TOURISM AND HOSPITALITY SECTION
}

\author{
László Papp, University of Pecs, Hungary
}

\begin{abstract}
The operational research is a so actual task, which is a binary, lineal inequality system, figures in the lecture onto its solution can be leaded back. In the article from among the solution methods three act: the simplex-method, the graphical solution, and the Excel spreadsheet Solver complement problem solving happening to its help. From among the solution manners the simplex method and the Excel the usage of spreadsheet Solver complement on the case of more of his changing uses applicable. The Excel the usage of spreadsheet Solver complement the thorough cognition of the first two methods and appears useful because we may manage to get quickly onto a result with its help after its drilling, and we may devote the time released to the analysis of the solution of the task and the interpretation of the meanings offered by Solver. (For the lecture this latter - analyses, interpretations - not its aim.)
\end{abstract}

Keywords: operational research, analyses, simplex method, Solver

JEL Codes:M1, D21, D83, D9

\section{Introduction}

Operational research and mathematical programming are interconnected: „mathematical programming seeks to minimise or maximise a multivariable function within a set defined by inequalities relating to multivariable functions. A special case is linear programming, where functions are linear." [1]

We present methods of solution to a specific problem below.

\section{The Problem}

In its spring offer, the Tourist Travel Agencies Office (TTAO) advertises two trips. It has three offices. The first office organizes one of the trips only, the second office deals with the other trip only, the third office organizes both and, apart from this, they sum up the orders, carry out the actual organization, realization. The first and second offices sell a trip within 5 time units, the free capacity of the first and second offices is 10 and 25 time units respectively. The capacity of the third office is 36 time units and the first and second trips require 6 and 4 time units respectively. On sale, the first and second trips carry 6 and 10 units of profit respectively. Let us determine how many of the trips are to be sold in order to maximise the profits.

\section{Solutions}

Based on the data at our disposal, we may draw up the following equation: 


$$
\left[\begin{array}{l}
5 \\
0 \\
6
\end{array}\right] x_{1}+\left[\begin{array}{l}
0 \\
5 \\
4
\end{array}\right] x_{2} \leq\left[\begin{array}{l}
10 \\
25 \\
36
\end{array}\right]
$$

We must provide a set of three numbers $\left[\mathrm{x}_{1}, \mathrm{x}_{2}, \mathrm{x}_{3}\right]$ in case of which the following objective function reaches its maximum:

$$
\mathrm{Z}=6 \mathrm{x}_{1}+10 \mathrm{x}_{2}
$$

Instead of the vectorial inequality, this may be stated as an equivalent system of inequalities:

$$
\begin{gathered}
5 \mathrm{x}_{1} \leq 10 \\
5 \mathrm{x}_{2} \leq 25 \\
6 \mathrm{x}_{1}+4 \mathrm{x}_{2} \leq 36 \\
\mathrm{x}_{1}, \mathrm{x}_{2} \geq 0 \\
\mathrm{Z}=6 \mathrm{x}_{1}+10 \mathrm{x}_{2} \rightarrow \max
\end{gathered}
$$

The problem data may be summed up in the following table:

Table no. 1

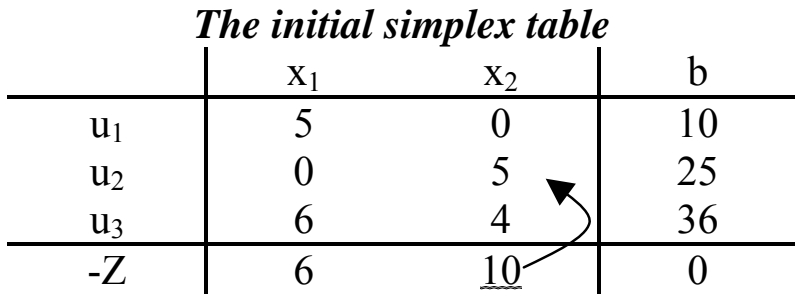

This table represents the situation before the start of production. It may be transformed by base transformation known from linear algebra.

Table no. 2

\begin{tabular}{c|cc|c}
\multicolumn{5}{c}{ The final simplex table } \\
& $\mathrm{u}_{1}$ & $\mathrm{u}_{2}$ & $\mathrm{~b}$ \\
\hline $\mathrm{x}_{1}$ & 1 & 0 & 2 \\
$\mathrm{x}_{2}$ & 0 & 1 & 5 \\
$\mathrm{u}_{3}$ & 0 & 0 & 0 \\
\hline$-\mathrm{Z}$ & 0 & 0 & -62
\end{tabular}

It can be seen from the table that two of the first type of trip and five of the second type of trip have to be organized in order to maximise profits; in this case the number of the units of profit is 62 .

Linear programming problems with two variables may also be solved graphically. 
As the first step of the graphic solution, we have to determine which points of the plane satisfy the criteria. (As a result of the formulation of the problem, variables cannot be negative; therefore it is sufficient to examine the first quarter plane.)

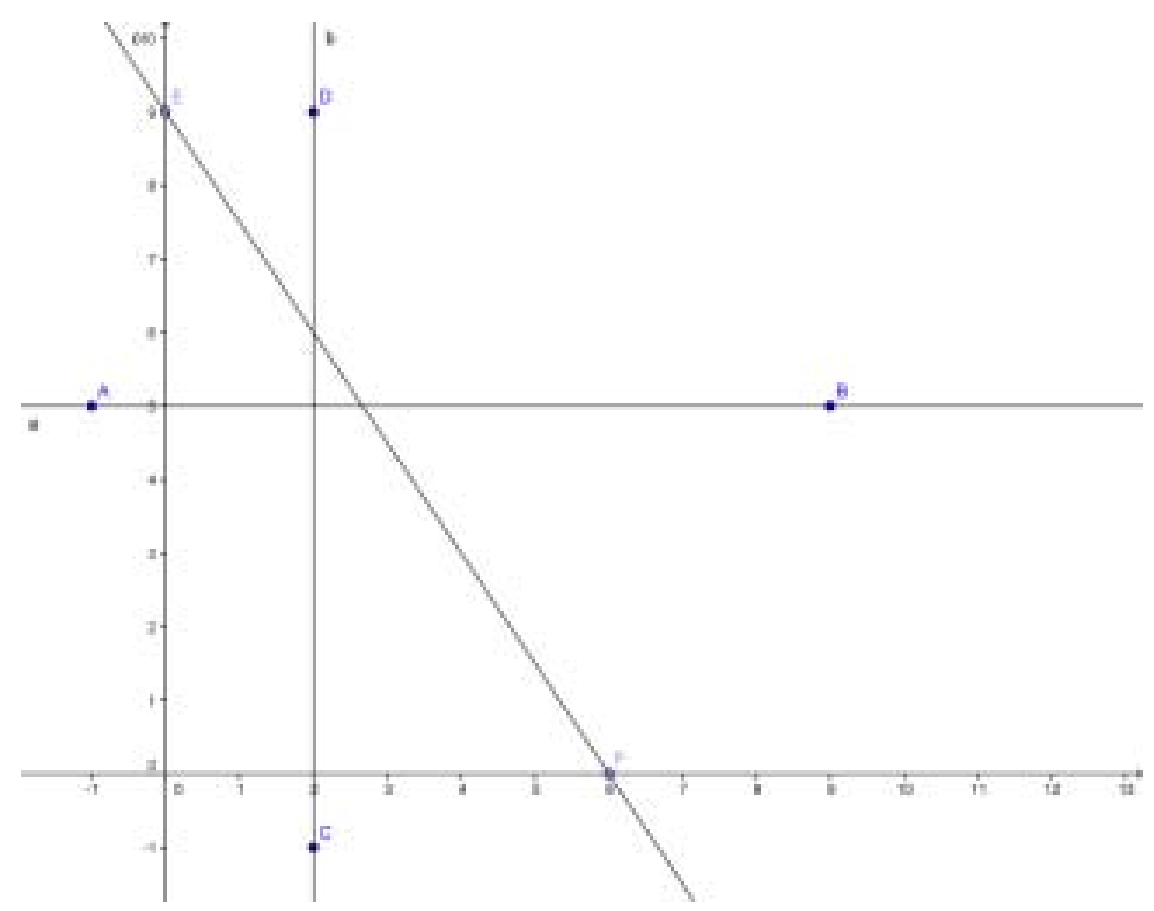

Fig. no. 1- Plotting of conditions criteria.

It is simple to see that the heavy lines and the coloured domain limited by them satisfy the

The second step is to determine the point of the maximum of the objective function. At first, one has to draw the points in relation to one given value of the objective function. (This should be the right line $20=6 x_{1}+10 x_{2}$, then the right line $40=6 x_{1}+10 x_{2}$.) These are the level lines connected to the values of $Z=20$ and $Z=40$. It may be seen that these right lines are parallel. If this shift is repeated several times, the level line will cross points of higher objective function values. This operation is to be continued until there is a common point with the set satisfying the criteria for the last time. This is where the optimum solution is found and the maximum profit may be determined. 


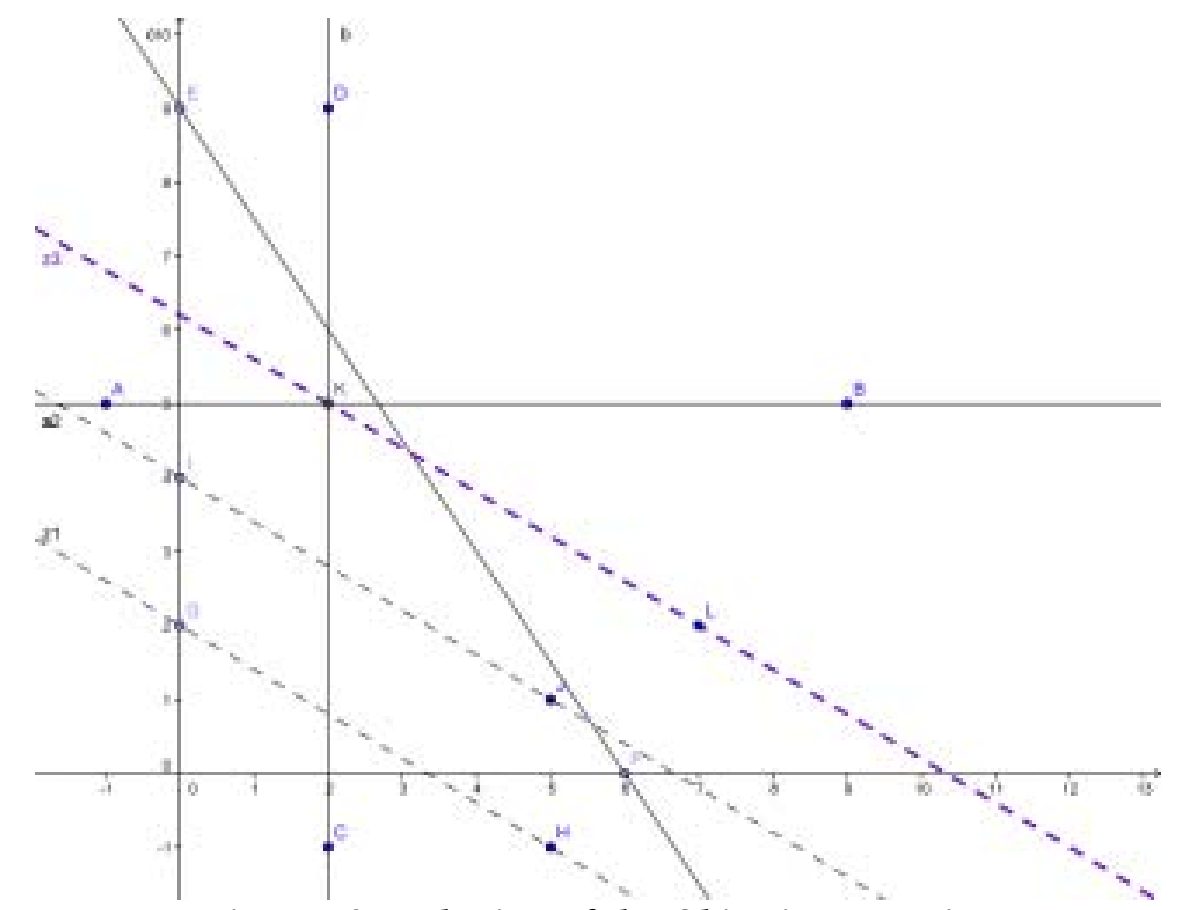

Fig. no. 2 - Plotting of the Objective Function

The problem may also be solved by the Excel spreadsheet Solver complement. This is a tool of analysis that helps to find the optimum (maximum, minimum or a specific) value attached to the formula in the target cell. Solver modifies the value of the given cells to be modified to reach the value given in the target cell as the final result. For the calculation, one may also set conditions limiting the variables; which can be exploited during problem solving.

During problem solving, one is to set out the data and formulae in the corresponding form, then parameters (target cell, variable cells, limiting conditions) are given with the help of the Solver complement.

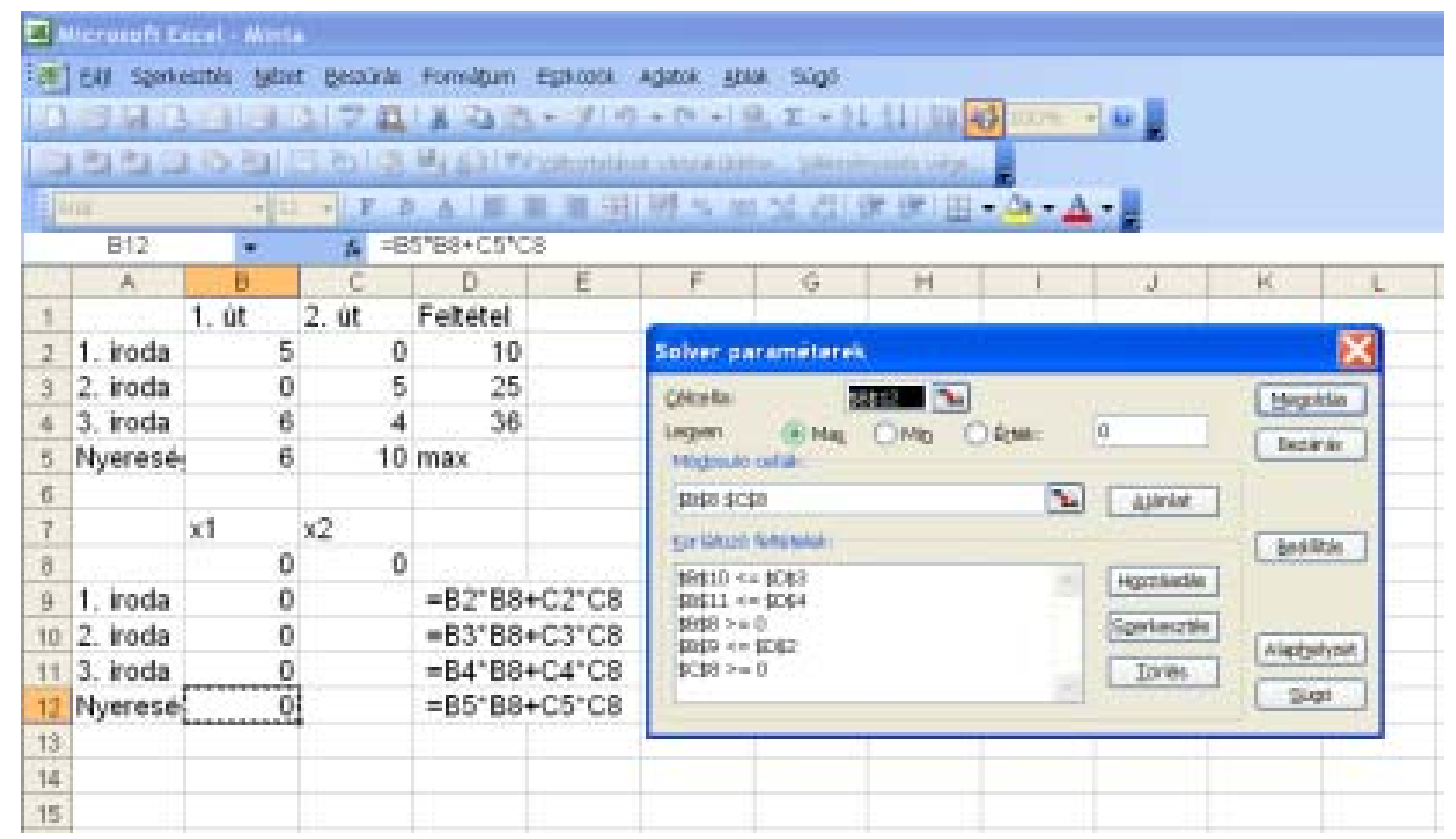

Fig. no. 3 - Data collection, parameter setting

The „Solution” key provides the desired solution through changing the cell content: 


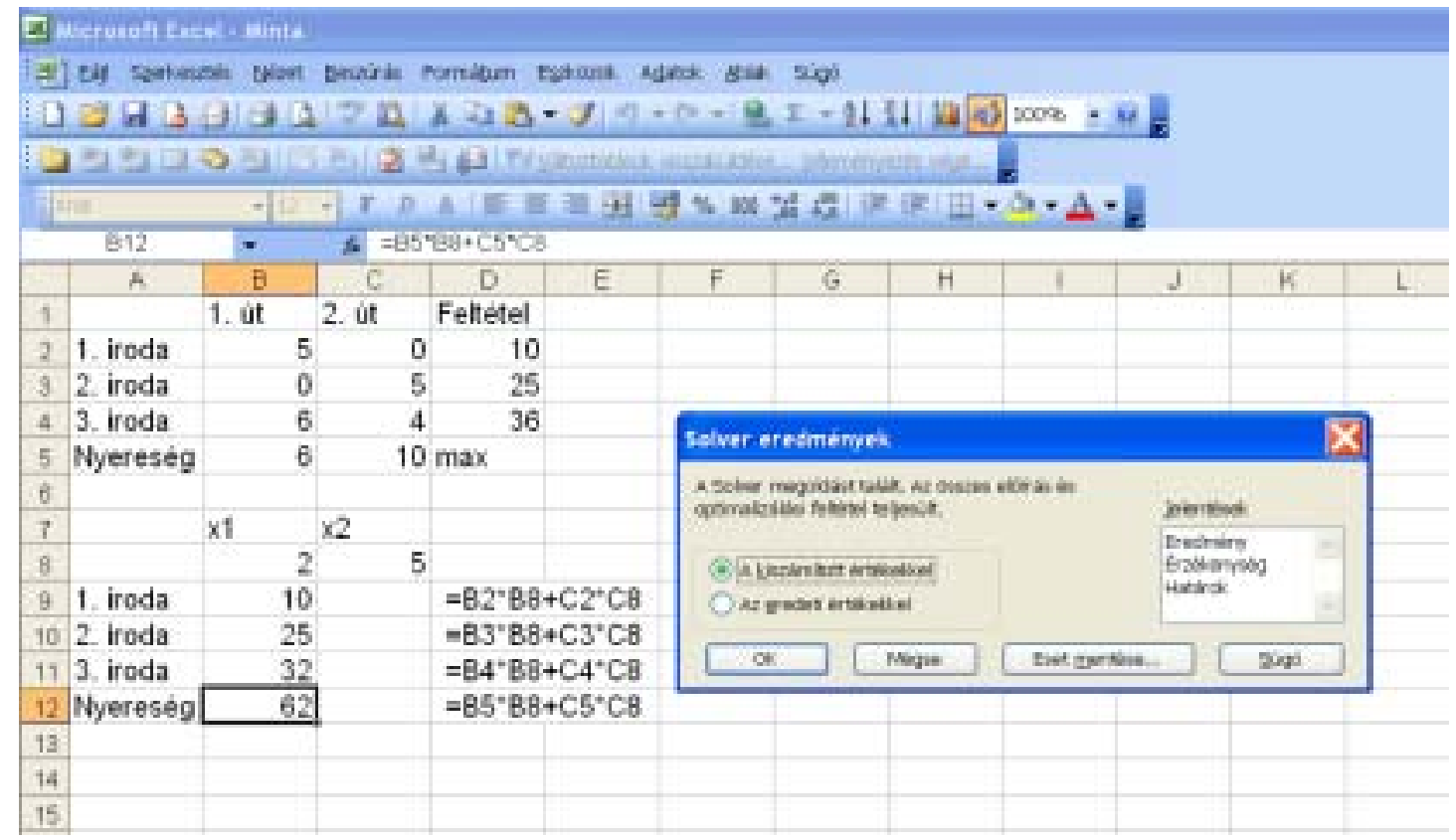

Fig. no. 4 - Determining the solution

Further on, we present cases where:

- One of the inequalities is not limiting either (similarly to the analysed problem),

- There are limiting conditions and there is a solution,

- One function describing the conditions corresponds to the target function, therefore there are several solutions.

In the cases analysed, we also provide the final Excel Solver solution. The Solver does not show the other existing solutions concerning the last-mentioned problem.

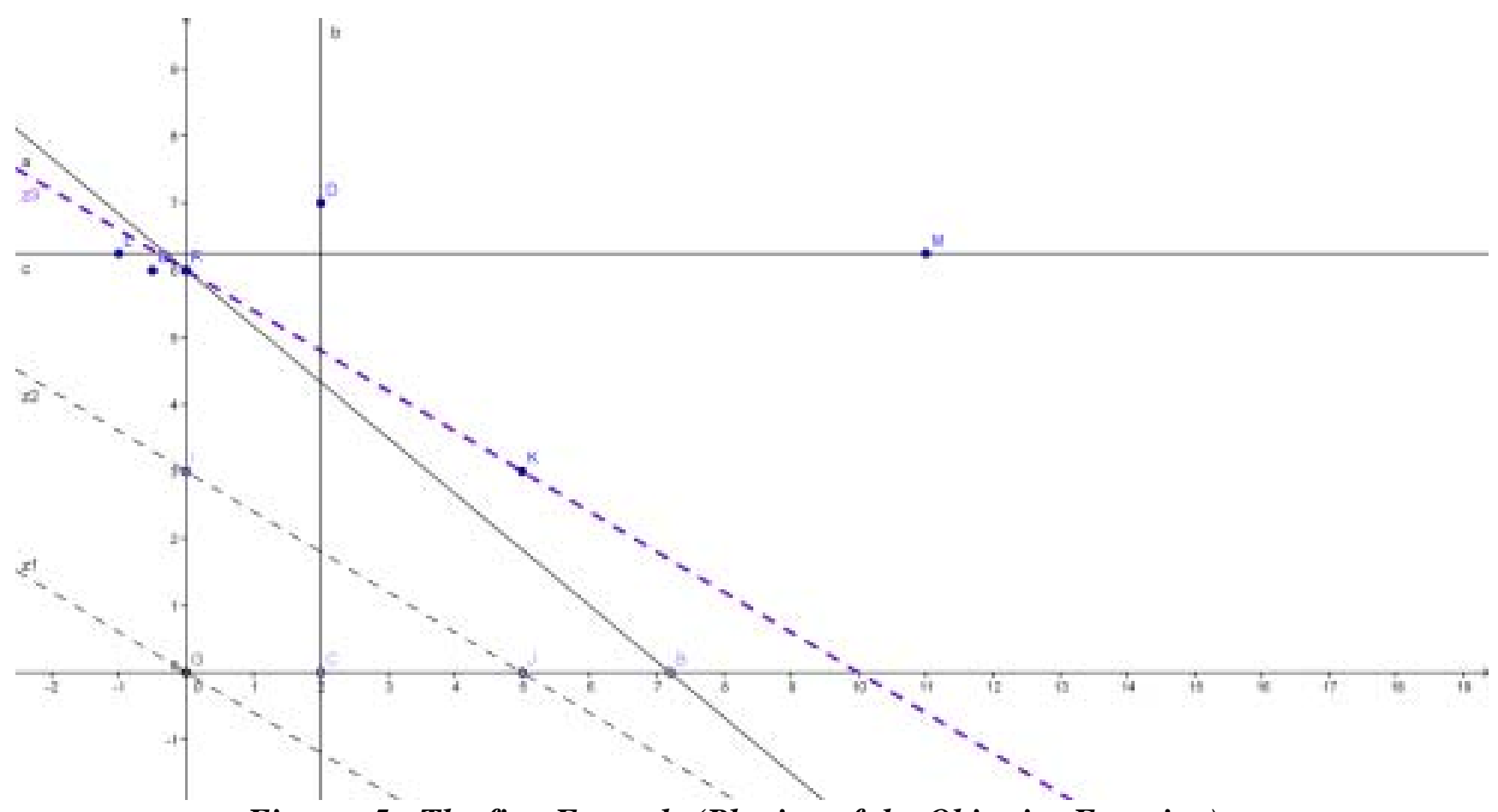

Fig. no. 5 - The first Example (Plotting of the Objective Function) 


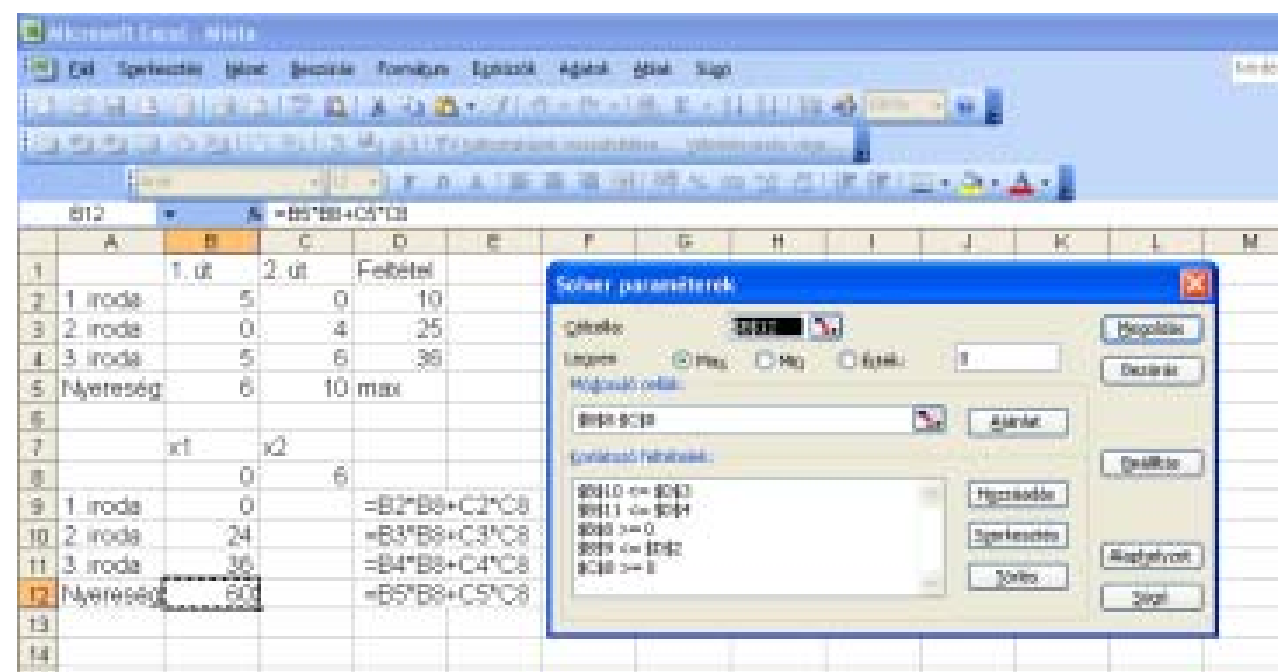

Fig. no. 6 - The first Example( Determining the solution)

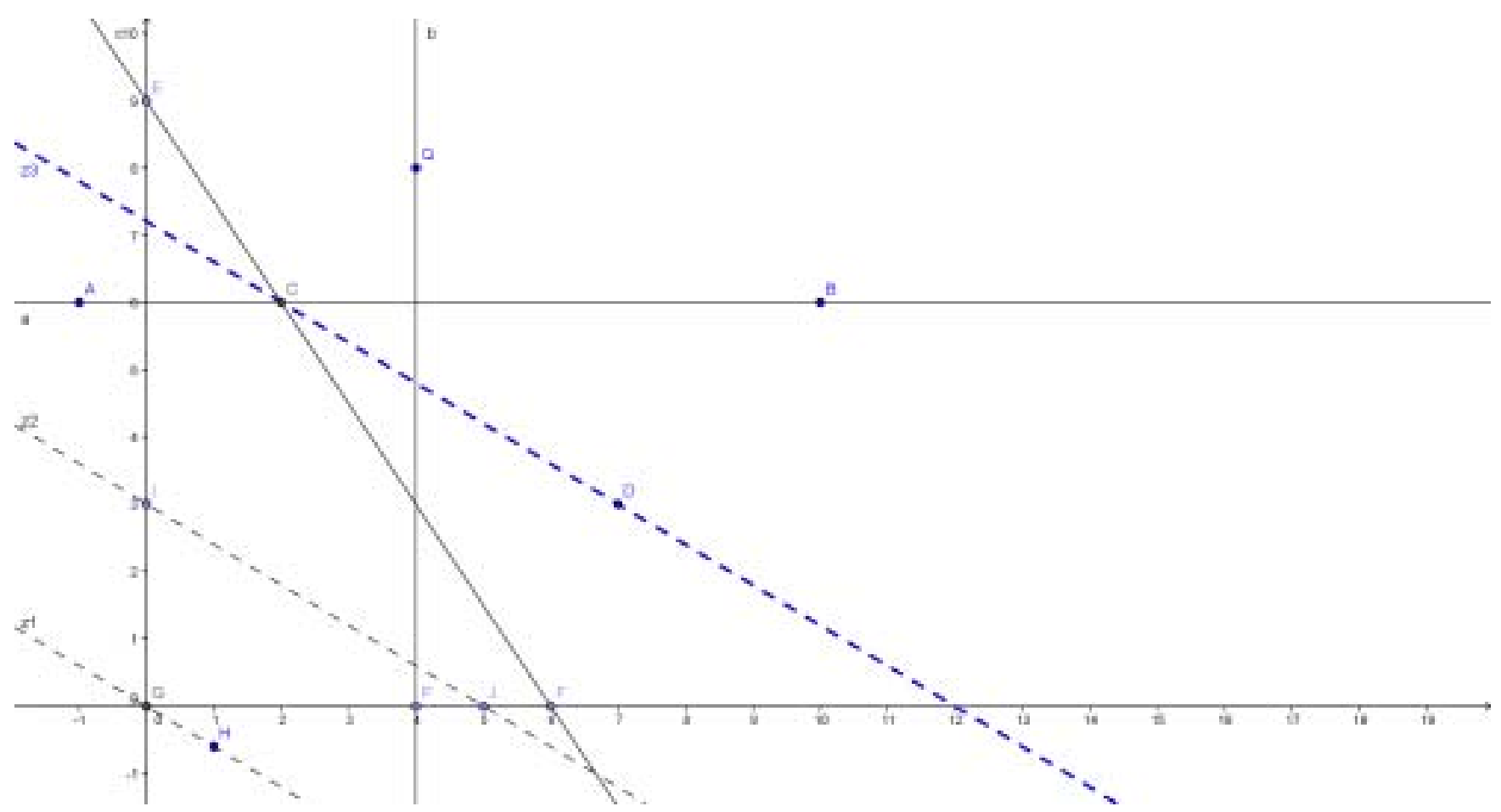

Fig. no. 7 - The second Example (Plotting of the Objective Function) 


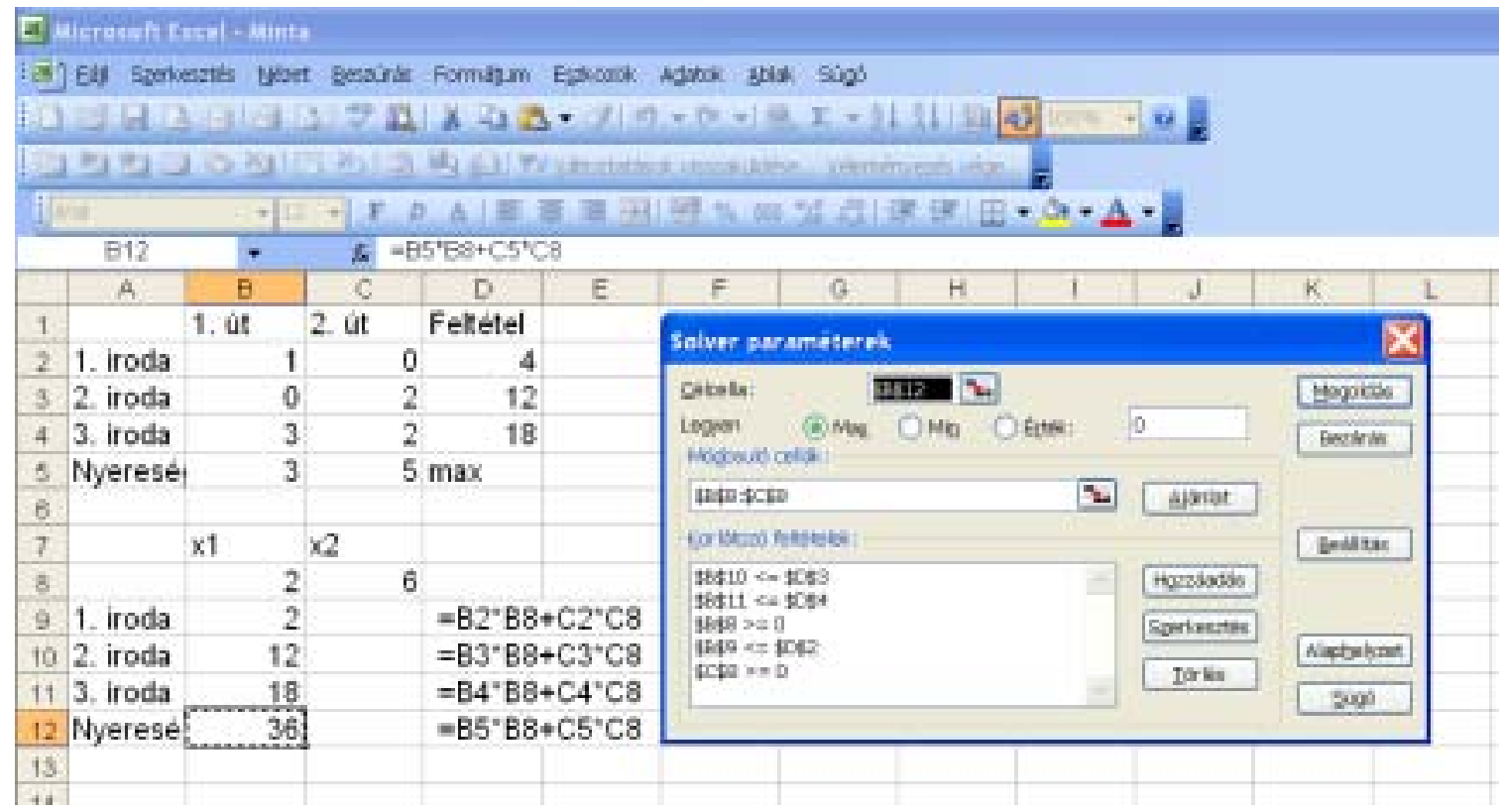

Fig. no. 8 - The second Example (Determining the solution)

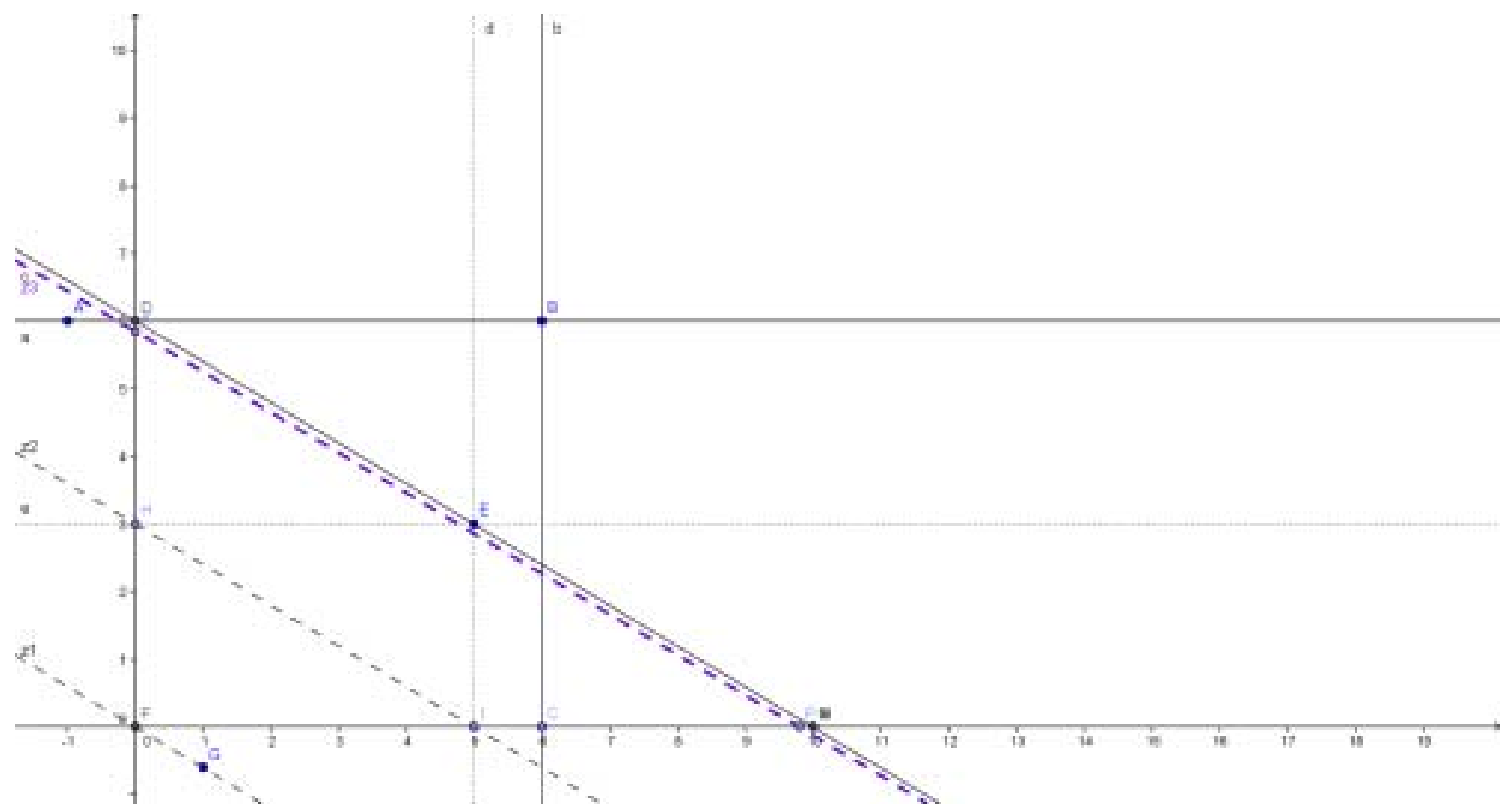

Fig. no. 9 - The third Example (Plotting of the Objective Function) 


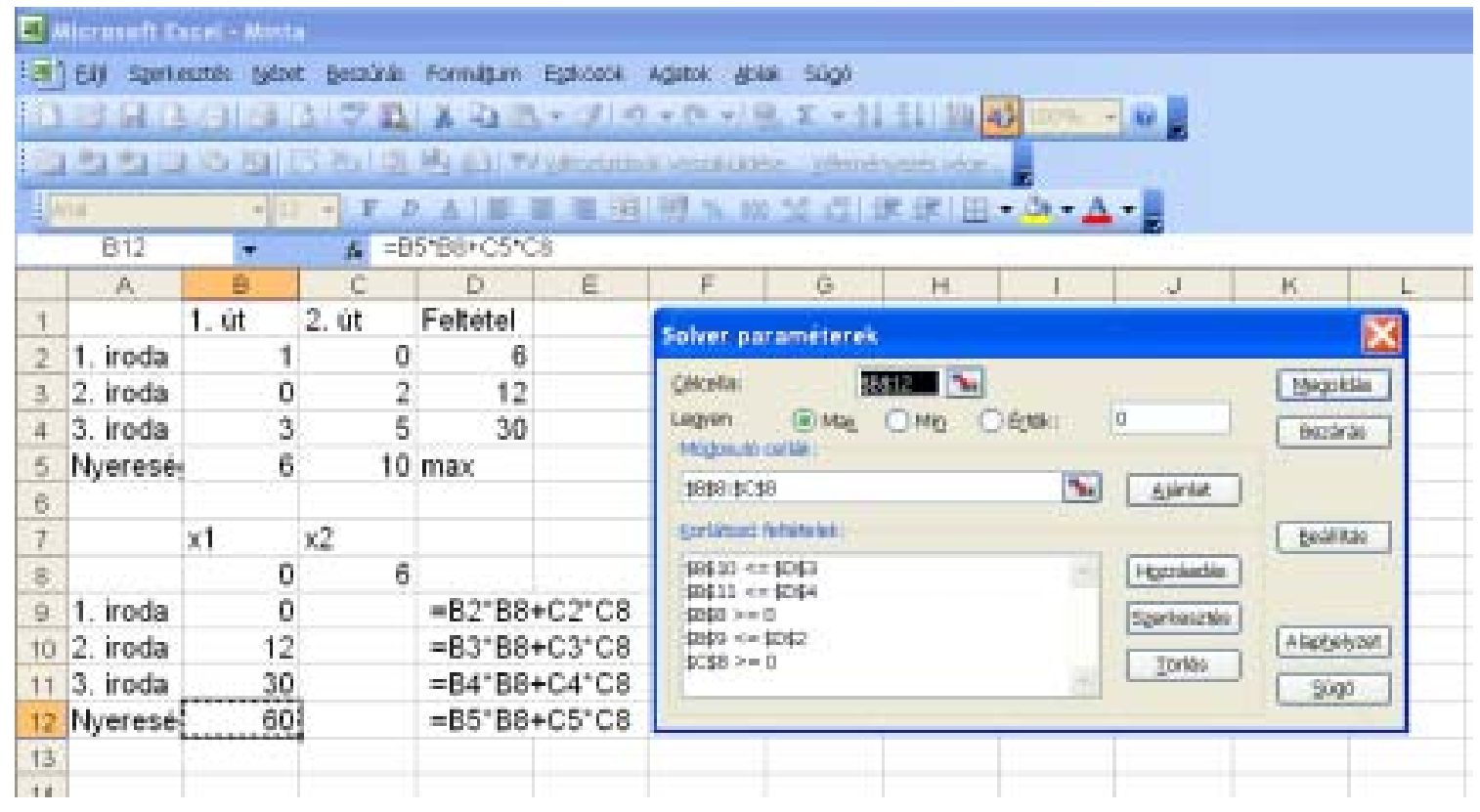

Fig. no. 10 - The third Example (Determining the solution)

In our examples, we examined a binary linear programming task. Naturally, during the mathematical solution - base transformation, simplex method - and the use of the Solver, it is possible to use several variables. (The Solver also uses the simplex method when determining the solution.)

I would especially like to thank Prof. Dr. Tamás Mellár for his professional assistance, Assoc. Prof. Dr. Levente Dimén PhD for the valuable help provided and Zsófia Zelnik for proofreading the English version.

\section{References}

1. Danyi, Pál - Zoltán Varró - Operációkutatás, lineáris programozás, (Előszó, V.), Pécs, 2001, p. V.

2. Hillier, Frederick S. - Gerald J. Lieberman - Bevezetés az operációkutatásba, LSI Oktatóközpont, Budapest, 1994. 